\title{
Slack And Crash Risk
}

\author{
Theodore Goodman, Purdue University, USA
}

Volkan Muslu, University of Houston, USA

Hyungshin Park, Santa Clara University, USA

\begin{abstract}
We examine how a firm's operational slack is associated with current income and future stock price crash risk. By doing so, we test the validity of a firm's alternative motivations for holding operational slack. We show that Supply Chain Slack, which is based on excess working capital, is associated with higher current profits and higher future crash risk. This evidence is consistent with the firm hoarding bad news. In contrast, SG\&A Slack, which is based on excess selling, general, and administrative expenses, is associated with lower current income and lower future crash risk. This evidence is consistent with the firm insuring against rare and adverse events. Furthermore, a firm's stock price crash risk is lower when a slack type is more costly, consistent with both motivations. Overall, our findings suggest a stronger profit-crash risk tradeoff when firms hold more operational slack.
\end{abstract}

Keywords: Crash Risk; Slack; Return on Equity

\section{INTRODUCTION}

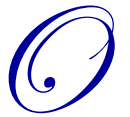

perational slack is a firm's resources that generate less value than typically expected. For instance, a firm can hold excess inventory, collect receivables late, and pay payables early. These working capital decisions tie up the firm's resources, lengthen cash flow cycle, and thus, all else equal, reduce profits. Similarly, a firm can spend excessively on employee salaries, employee benefits, R\&D, and advertising. These operating expenses mechanically reduce profits. The strategic management and operations management literatures have searched for potential benefits of operational slack (in the form of current and future profits) that counter the mechanical costs. Yet, the findings are mixed (Daniel, Lohrke, Fornaciari \& Turner, 2004; Modi \& Mishra, 2011; Kovach, Hora, Manikas \& Patel, 2015).

If operational slack does not generate benefits to counter mechanical costs, how would a firm with operational slack thrive in the long run? We address this question by examining a firm's future stock price crash risk, which are realized or expected large, negative, and discontinuous movements in a firm's stock price. ${ }^{1}$ Note that we focus on a firm's downside risk - not the firm's valuation or upside potential - given that a firm's long-term competitiveness depends on its downside risk. Moreover, investors conceptualize a firm's risk by the downside risk despite the predominantly symmetric risk measures in the finance literature (Miller \& Reuer, 1996; Jin \& Myers, 2006).

There are four explanations for why a firm holds operational slack. Each explanation predicts different outcomes in current profits and future stock price crash risk. First, under the premise of effective management, a firm can have operational slack to offset rare and adverse events such as disruptions in supply chain and inflation (insurance explanation). In this case, current profits should be lower because of the sub-optimal use of resources, and stock price crash risk should be lower as well (Chopra \& Sodhi, 2004; Hendricks, Singhal \& Zhang, 2009). Second, under the premise of ineffective management, a firm can have operational slack that does not maximize shareholder value (poor management explanation). In this case, current profits should be lower, and stock price crash risk should be higher. Third, under the premise of strong agency costs, a firm can have operational slack to defer reporting low profits ( $\mathrm{bad}$ news hoarding explanation). For instance, the firm can delay impairment of inventory and receivables. In this case, current profits should be higher as intended, and stock price crash risk should be higher (Jin \& Myers, 2006, Hutton,

\footnotetext{
${ }^{1}$ We measure stock price crash risk in two ways. The negative skewness of stock returns measures the frequency and severity of realized stock price crashes (Chen, Hong \& Stein, 2001). The negative skewness of implied volatilities for traded options measures investors' expectations of a future stock price crash (Kim, Li, Lu \& Yu, 2016).
}

Copyright by author(s); $\underline{\text { CC-BY }}$ 
Marcus \& Tehranian, 2009). Finally, under the premise of effective management, a firm can have operational slack to accommodate current and expected growth (accommodating growth explanation). For instance, the firm can have high selling, general, and administrative (SG\&A) costs (Anderson, Banker \& Janakiraman, 2003) and hold high levels of inventory (Bernard \& Noel, 1991; Sun, 2010). In this case, current profits should be higher, and stock price crash risk should be lower.

We test the above explanations by using two major types of slack, which have different accounting treatments yet collectively capture a firm's major operational decisions. Supply Chain Slack measures a firm's excess cash flow cycle, which is determined by working capital decisions. Supply Chain Slack is capitalized and does not mechanically reduce current profits. $S G \& A$ Slack measures a firm's excess SG\&A expenses, which is determined by other operational decisions. $S G \& A$ Slack is immediately expensed.

We find, on average, that a firm's current profits and future crash risk both increase with Supply Chain Slack, consistent with the bad news hoarding explanation. In contrast, current profits and future crash risk both decrease with $S G \& A$ Slack, consistent with the insurance explanation. Furthermore, both slack types strengthen the typically positive association between a firm's current profits and future stock crash risk. In other words, operational slack that reduces (does not reduce) current profits also reduces (does not reduce) stock price crashes. This is consistent with both the bad news hoarding and insurance explanations.

Our study makes the following contributions. First, it helps us to understand the benefits of operational slack. The operations management and strategic management literatures have failed to document that operational slack universally improves current or future profits (Daniel et al. 2004; Kovach et al. 2015). This is likely because slack's earnings-related benefits do not fully offset slack's mechanical costs. Moreover, prior studies used different samples and slack definitions (Greenley \& Oktemgil, 1998; Mishina, Pollock \& Porac, 2004), hypothesized different timelines between operational slack and performance (Daniel et al. 2004), and ignored firms' measurement errors as well as earnings management incentives. Our paper puts forward reduced stock price crashes as a potential benefit of slack, especially under conditions of low current profits. A slack that is associated with low profits is also associated with reduced stock price crashes, thereby contributing to firm's long-run chances for survival. Our findings answer Daniel's et al. (2004) call for additional research into intervening factors that impact the slack-performance relationship as well as George's (2005, p. 672) call for future research "from the simple question of whether slack is good for performance to a more complex set of questions: How much and what form of slack is good for performance and when is slack good for performance?"

Second, our study contributes to the literature on the determinants of stock price crash risk. The findings in the literature primarily suggest bad news hoarding as the primary explanation for crash risk. Yet the studies have ignored operational slack as a potential determinant. We show that operational slack impacts a firm's stock price crash risk in different ways. Profit-reducing slack decreases future crash risk (consistent with insurance explanation) while profitneutral and profit-increasing slack increases future crash risk (consistent with bad news hoarding explanation). This evidence also complements a recent finding by Francis, Hasan \& Lingxian (2016) that crash risk increases with the extent a firm deviates real operations from industry norms, especially with the purpose of managing earnings upwards.

Finally, our research contributes to the debate on how firms do (should) manage their risks. Bodnar, Graham, Harvey \& Marston's (2011) global survey finds that firms have been increasingly managing their risks through operational decisions such as holding slack. The financial crisis of 2008 elevated the issue of firm-specific risk management to the forefront from a public policy perspective. Thus, public policy makers can use our findings about the effectiveness of operational slack, particularly for firms that have a systemic role in the economy.

The remainder of the paper is organized as follows. Section 2 develops hypotheses by linking different strands of literature about slack and crash risk. Section 3 describes research design. Section 4 presents sample selection and findings. Section 5 concludes. 


\section{HYPOTHESIS DEVELOPMENT}

\subsection{Operational Slack Definitions and Profits}

We compute two operational slack proxies. First, Supply Chain Slack measures the sub-optimal deployment of a firm's working capital (Hendricks et al. 2009; Kovach et al. 2015). Supply Chain Slack is defined as Inventory Slack + Receivables Slack + Payables Slack. Inventory Slack is the level of inventory scaled by cost of goods sold (COGS). Receivables Slack is the level of trade receivables scaled by sales. Payables Slack is the level of trade payables scaled by COGS, multiplied by negative one. Inventory Slack, Receivables Slack, and Payables Slack interact and affect the operating cash cycle of a firm in similar ways. A higher Supply Chain Slack indicates a longer operating cash cycle, that is, a higher level of inventory and receivables, and a lower level of payables for a given level of sales. The second proxy $S G \& A$ Slack is defined as selling, general, and administrative expense scaled by sales revenue (Driouchi \& Bennett, 2011). A higher $S G \& A$ Slack indicates high levels of investment in employees (e.g., higher staff salaries, pension), intangible assets (e.g., R\&D and advertising), and other periodic costs (e.g., rental or depreciation costs).

The direct effect of $S G \& A$ Slack on current profits is negative, because components of $S G \& A$ Slack are expensed. However, this effect could be offset by indirect benefits (e.g., higher sales revenues as a result of higher advertising expenses, higher productivity as a result of highly paid employees). In their meta-analysis of 66 prior studies, Daniel et al. (2004) find a positive - albeit weak - relation between $S G \& A$ Slack and current profits, consistent with potential benefits of holding $S G \& A$ Slack offsetting the mechanical costs.

The effect of Supply Chain Slack on current profits is not as trivial, because components of Supply Chain Slack are not expensed. Empirically, excess working capital reduces asset turnover and current profits under a stable business environment (Modi \& Mishra, 2011). Similarly, there is negative, yet concave, relation between inventory slack and profits (Eroglu \& Hofer, 2011). At the same time, Supply Chain Slack can suggest a firm's optimally addressing unexpected threats and opportunities and generating profit under an unstable business environment (Kovach et al. 2015). Profits first increase with slack and then decrease with additional slack (George, 2005). In their meta-analysis, Daniel et al. (2004) find a positive relationship between working capital slack and current and future profits. Similarly, a strand of accounting research documents inconsistent findings. A high level of net operating assets, which reflects a high level of Supply Chain Slack, is associated with strong profits possibly due to earnings management, followed by weaker future profits (Fairfield, Whisenant \& Yohn, 2003; Hirshleifer, Hou \& Teoh, 2004).

In addition to operational slack, companies also have investment and financial slack, such as excess cash balance, PP\&E, and intangibles, financial debt, and potential for additional debt. We focus on operational slack while controlling for such financial and investment slack.

\subsection{Motivations for Holding Operational Slack}

While outsiders can observe operational slack from financial statements, they cannot observe managers' motivations for holding operational slack. Below we provide four ways outsiders could explain managers' motivation for holding operational slack, which have different implications on current profits and future crash price risk.

\subsection{Insurance Against Downside Risk}

The notion of downside risk appears across various streams of literature. In psychology, the prospect theory predicts and finds that individuals asymmetrically react to the prospect of losses (Kahneman et al. 1982). In finance, a downside risk model can explain stock returns better than the traditional Capital Asset Pricing Model, which treats positive and negative return volatility symmetrically (Harlow \& Rao, 1989; Ang et al. 2006). In strategic management literature, managers and financial analysts consider risk as the size and probability of losses rather than the size and possibility of positive outcomes (Baird \& Thomas, 1990; Collins \& Ruefli, 1992; Reuer \& Leiblein, 2000). Porter (1985, p. 476) states: "Risk is a function of how poorly a strategy will perform if the "wrong" scenario occurs." 
Under the premise of effective management, operational slack can reduce the frequency and cost of an adverse event. For instance, operational slack helps to mitigate the adverse stock price reaction to supply chain disruptions (Hendricks et al. 2009). Excess credit to customers helps firms to establish a long-term relationship with customers (Wilner, 2000; Cunat, 2007). A low level of payables helps to develop favorable relations with suppliers and improve terms of borrowing with creditors. Firms can have high personnel costs due to meticulous internal controls (e.g., more employees tasked with oversight), which mitigate adverse events. High salaries and pensions can help retain talent and reduce employee turnover. High R\&D and advertising expenses help to develop high-quality products and maintain customer loyalty, thereby mitigating operational risks. In addition, firms can cut some of these costs to meet profit targets and preserve liquidity when they face rare and adverse conditions (Bushee, 1998; Cohen, Mashruwala \& Zach, 2010; Kovach et al. 2015). Overall, a firm will have both low current profits and low future crash risk when it uses operational slack for insurance purposes.

\subsection{Poor Management}

Under the premise of ineffective management, managers cannot assess optimal slack levels while attempting to maximize share value. For instance, firms that hold high levels of inventory to insulate from supply chain disruptions may reduce immediate risks to inventory shortage but give rise to the risk of inventory obsolescence. Under the wasteful spending view of poor management, managers hold slack to benefit their vested interests despite little to no benefit to shareholders (John, Li \& Pang, 2017). For instance, firms with overly compensated employees and nonoptimal advertising and R\&D expenses may not be insulated from adverse shocks. In either case, the poor management explanation suggests that poor management of risk (Kovach et al. 2015). Overall, a firm will have low current profits and high future crash risk when operational slack results from poor management.

\subsection{Bad News Hoarding}

Under the premise of agency costs, managers can conceal bad news and avoid recording expenses for an extended period. For example, high levels of inventory and receivables may indicate inability to sell inventory and collect receivables combined with managers' reluctance to write off inventory and receivables. In this case, Supply Chain Slack indicates bloated balance sheet due to a history of bad news hoarding (Hirshleifer et al. 2004). When bad news cannot be held anymore, stock prices crash (Jin \& Myers, 2006; Hutton et al. 2009; Zhu, 2016). Overall, a firm will have both high current profits and high future crash risk when it hoards bad news. This explanation is valid only for Supply Chain Slack. In contrast, SG\&A Slack indicates immediate recording of expenses and less likelihood of hoarding bad news.

\subsection{Accommodating Growth}

Under the premise of effective management, managers realizing or expecting high growth hold more working capital and recognize higher SG\&A expense (Anderson et al. 2003). Similarly, increases in inventory-to-sales ratio may indicate managers' optimistic expectations on sales and profits (Bernard \& Noel, 1991; Sun, 2010). Moreover, managers' growth expectations are accurate for a large proportion of firms (Anderson, Banker, Huang \& Janakiraman, 2007). Overall, a firm will have high current profits and low future crash risk when it uses operational slack to accommodate growth.

\section{RESEARCH DESIGN}

\subsection{The Relation between Slack and Stock Price Crash Risk}

We estimate the following regression model to examine the relation between operational slack and stock price crash risk:

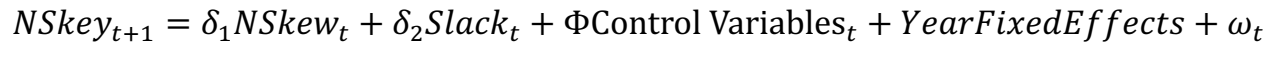

$$
\begin{aligned}
& \text { IVSkew }_{t}=\delta_{1} \text { IVSkew }_{t-1}+\delta_{2} \text { Slack }_{t}+\text { TControlVariables }_{t}+\text { YearFixedEffects }+\omega_{t}
\end{aligned}
$$


Equation (1a) estimates the determinants of an ex-post measure of crash risk. NSkew $w_{t+1}$ is the skewness of the firm's weekly stock returns during year $t+1$, multiplied by negative one. The literature defines stock price crash risk using idiosyncratic returns (Kim, Li \& Zhang, 2011a; Kim, Li \& Zhang, 2011b). While our findings are robust to this definition, we define crash risk using raw returns to avoid confounding effects of return prediction models.

Equation (1b) estimates the determinants of an ex-ante measure crash risk. Expectations of stock price crashes are as important to capital markets as realized crashes. Kim et al. (2016) argue that investors "demand a much larger risk premium for expected crash risk than for historical crash risk." Bollerslev and Todorov (2011) find historically large equity and variance risk premia for jump tail risk, especially left tail (disaster or fear risk). Consistent with finance literature (Dumas, Fleming \& Whaley, 1998; Bollen \& Whaley, 2004; Kim, Li, Lu \& Yu, 2016), we use option smirk curve or implied volatility skewness as the proxy for ex ante crash risk. Specifically, IVSkew $t$ is the weighted average of daily differences between implied stock return volatilities of out-of-the-money put options and at-the-money call options over the 12 months ending three months after the end of fiscal year $t$.

Equations (1a) and (1b) include lagged crash risk, slack, current profits, and control variables. The lagged crash risk proxies (i.e., NSkewt, and IVSkewt-1) control for persistent firm characteristics. We use the following financial control variables:

\begin{tabular}{|c|c|c|}
\hline$R O E$ & $=$ & Net income divided by shareholder's equity, \\
\hline Loss & $=$ & Indicator that is one if income before extraordinary items is negative, \\
\hline Return & $=$ & Annual raw stock returns, \\
\hline Firm Efficiency & $=$ & $\begin{array}{l}\text { Demeriian, Lev \& McVay's (2012) measure of total firm efficiency, measuring a firm's } \\
\text { ability in transforming resources to revenue, }\end{array}$ \\
\hline Managerial Ability & $=$ & $\begin{array}{l}\text { Demeriian et al.'s (2012) measure of managerial ability, which is the residual firm efficiency } \\
\text { that cannot be explained by firm-specific variables, }\end{array}$ \\
\hline Log(Assets) & $=$ & Natural logarithm of total assets, \\
\hline Number of Analysts & $=$ & The number of analysts making stock recommendations on the firm, \\
\hline$B / M$ & $=$ & Book value of total assets divided by market value of total assets, \\
\hline Return Volatility & $=$ & Standard deviation of weekly stock returns, \\
\hline Trading Volume & $=$ & Annual trading volume divided by the average number of shares outstanding, \\
\hline Beta & $=$ & $\begin{array}{l}\text { Coefficient estimate for industry return, obtained from firm and year-specific regressions of } \\
\text { a firm's weekly returns on SIC 2-digit industry returns, negative industry return indicator, } \\
\text { and interaction of industry returns and negative industry return indicator (See } A 1 \text { in the } \\
\text { Appendix), }\end{array}$ \\
\hline Age & $=$ & $\begin{array}{l}\text { The number of years since the firm's stock appeared in the CRSP/Compustat database (1980 } \\
\text { is the starting year), }\end{array}$ \\
\hline Accruals & $=$ & $\begin{array}{l}\text { Change in net operating assets, computed as total assets }(a t) \text {-cash and short-term } \\
\text { investments }(c h e) \text {-total liabilities }(l t)+\text { debt in current liabilities }(d l c)+\text { +long-term debt }(d l t t) \\
\text { in the CRSP/Compustat database, }\end{array}$ \\
\hline Cash & $=$ & Cash and short-term investments (che) divided by total assets, \\
\hline LR ETR & $=$ & $\begin{array}{l}\text { Long-run effective tax rate, computed as the sum of income tax paid (txpd) over the previous } \\
\text { five years divided by the sum of a firm's pre-tax income minus special items ( } p i-s p i \text { ) } \\
\text { (Dyreng, Hanlon \& Maydew, 2008). When the special item is missing, it is set to zero. } L R \\
\text { ETR is winsorized at } 0 \text { and } 1 \text {, }\end{array}$ \\
\hline Auditor Tenure & $=$ & $\begin{array}{l}\text { The number of years the incumbent auditor has been auditing the firm (Callen \& Fang, } \\
\text { 2017). }\end{array}$ \\
\hline
\end{tabular}

All regression variables except for year fixed effects and indicator variables are ranked to vary between zero and one within a firm's SIC 2-digit industry. This ranking mitigates the effect of outliers and controls for unobservable industry characteristics that affect crash risk and slack (Daniel et al. 2004; Wefald, Katz, Downey \& Rust, 2010). The control variables include potential determinants of slack. Including these variables in the same models as slack amounts to running a first-stage model to determine excess slack based on these variables and then using excess slack in the 
second-stage model to predict crash risk. We chose a single-step approach to be transparent on the use of our control variables and the incremental impact of operational slack on crash risk.

\subsection{Conditioning on Firm Profitability}

The explanations outlined in Section 2 predict the associations between slack and current profits and future crash risk as follows:

\begin{tabular}{|c|c|c|c|}
\hline \multirow{4}{*}{$\begin{array}{l}\text { Association between Operational } \\
\text { Slack and Current Profits }\end{array}$} & & \multicolumn{2}{|c|}{$\begin{array}{l}\text { Association between Operational Slack and Future Crash } \\
\text { Risk }\end{array}$} \\
\hline & & Positive & Negative \\
\hline & Positive & Bad News Hoarding & Accommodating Growth \\
\hline & Negative & Poor Management & Insurance \\
\hline
\end{tabular}

Overall, the prediction for operational slack and future crash risk depends on the assumption about slack and current profit. The insurance and bad news hoarding explanations predict a trade-off between current profit and future crash risk, where operational slack has similar correlations with current profit and future crash risk. In contrast, the poor management and accommodating growth explanations predict that operational slack has opposite correlations with current profit and future crash risk.

We devise cross-sectional tests based on current profits in order to examine the empirical validity of these explanations. For example, we can distinguish between the insurance and poor management explanations by examining the effect of slack on future crash risk when current profits are low. According to the insurance explanation, low profits reflect costly risk management activities and thus low future crash risk. According to the poor management explanation, low profits reflect inefficiencies and thus high future crash risk. We allow the association between slack and stock price crash risk to vary with accounting profits by including interaction variables into Equations (1a) and (1b). This results in the following model:

NSkew $_{t+1}$ or IVSkew $_{t}=\delta_{1}\left(\right.$ NSkew $_{t}$ or IVSkew $\left._{t-1}\right)+\delta_{2}$ Slack $_{t}+\delta_{3}$ ROE $_{t}+\delta_{4}$ Slack $_{t} *$ ROE $_{t}+$ VVariables $t+$ YearFixedEffects $+\omega_{t}$

The interaction term $\operatorname{Slack}_{t}{ }^{*} R O E_{t}$ allows the effect of slack to change with profits. $R O E_{t}$ remains as a control variable.

The insurance and bad news hoarding explanations separately predict a positive coefficient on the interaction term. First, operational slack is more likely to increase future crash risk when profit is high due to bad news hoarding. Second, operational slack is more likely to decrease future crash risk when profit is low due to insurance activities. In contrast, the poor management and accommodating growth explanations separately predict a negative coefficient on the interaction term. First, operational slack is more likely to increase future crash risk when current profit is poor due to poor management. Second, operational slack is more likely to decrease crash risk when current profit is high due to growth expectations.

\section{EMPIRICAL RESULTS}

\subsection{Sample}

Our sample consists of firms in the CRSP/Compustat database for years between 1990 and 2013. We remove financial firms given that operational slack is trivial in the finance industry. In order to avoid small denominator problems, we remove firms with assets, sales, shareholders' equity, and COGS smaller than $\$ 1$ million. We also remove observations with missing crash risk proxies, slack types, and financial control variables. Our final sample includes 71,018 firmyear observations. 


\subsection{The Relation between Operational Slack and Negative Skewness of Stock Returns}

For the ensuing tests, we rank all variables to vary between 0 and 1 within SIC 2-digit industry groups for two reasons. First, industry membership shapes a firm's slack policies and crash risk, and failure to adequately control for industry effects may result in false inferences. Second, the ranking mitigates the effect of outliers.

Table 1 presents the results of Equation (1a), where the dependent variable is NSkew ${ }_{t+1}$. Column 1 shows that Supply Chain Slack $k_{t}$ is positively associated with $N_{\text {Skew }}{ }_{t+1}$, consistent with excess working capital accounts signaling or amplifying one-year-ahead crashes. The overall evidence is consistent with the bad news hoarding explanation, given that Supply Chain Slack does not decrease current profits and could in fact represent a history of upward earnings management (e.g., Hirshleifer et al. 2004). Column 2 shows that $S G \& A$ Slackt is negatively associated with NSkewt+1. The overall evidence is consistent with the insurance explanation, given the negative association between SG\&A Slack and current profits. When both slack types are included in Column 3, the coefficient magnitudes and significances remain. In terms of economic significance, moving Supply Chain Slack from the lower to the higher half of its distribution increases $N S k e w_{t+1}$ by $(0.015 * 50 \%=) 0.008$ or $2.8 \%$ of standard deviation of $N$ Skew $w_{t+1}$, whereas moving

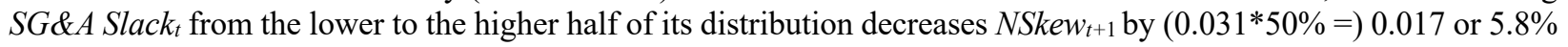
of standard deviation of NSkew $t+1$.

We perform several sensitivity tests. First, we replace $N$ Skew $w_{t+1}$ with $N$ Skew $w_{t+1, t+2}$, which uses weekly stock returns from years $t+1$ and $t+2$. When we re-estimate Eq. (1) using NSkewt $w_{t+1} t+2$ as the dependent variable (Column 4), the coefficient estimates for Supply Chain Slackt and $S G \& A$ Slack $t$ are weaker but statistically significant. Second, we replace $N S k e w_{t+1}$ with $D N S k e w_{t+1}$, which uses daily stock returns from year $t+1$. When we re-estimate Eq. (1) using DNSkew $t_{t+1}$ as the dependent variable (Column 5), the coefficient estimates for Supply Chain Slack and SG\&A Slack are significant. Third, in untabulated tests we use raw values of all variables in Eq. (1) and find that the signs and economic significance of coefficient estimates for Supply Chain Slack $k_{t}$ and SG\&A Slackt remain consistent.

The coefficients for control variables are consistent with the expectations and past findings. NSkew $w_{t+1}$ is higher when 1) firms have higher $N S k e w t, 2$ ) they had higher profits and did not report accounting losses, 3) they had higher stock returns, 4) they were larger, 5) they were followed by more analysts, 6) they had high growth expectations (low B/M ratio), 7) they had low stock return volatility and high trading volume, 8) they had low betas, or 9) they had higher effective tax rates (Kim et al. 2011a). NSkew $t_{t+1}$ is not significantly related with 1) variables that measure firm efficiency and managerial ability in transforming resources to sales (Demerjian et al. 2012), 2) company age, 3) accrual levels (Zhu, 2016), 4) cash balances, or 5) auditor tenure (Callen \& Fang, 2017). One inconsistency between our findings and the literature is that Return Volatility $y_{t}$ and Beta $t_{t}$ are negative in our tests while they are positive and significant (Kim et al. 2011a, p. 650; Kim et al. 2011b, p. 721) or insignificant (Zhu, 2016, p. 336) in prior studies. This inconsistency likely arises because of strong correlations among Return Volatility, Betat, and NSkew $t_{t+1}$ in our sample. 
Table 1. The Relation between Slack and Negative Skewness of Stock Returns

\begin{tabular}{|c|c|c|c|c|c|}
\hline \multirow{3}{*}{ NSkew $_{t}$} & NSkew $_{t+1}$ & NSkew $_{t+1}$ & NSkew $w_{t+1}$ & NSkew $_{t+1, t+2}$ & DNSkew $w_{t+1}$ \\
\hline & $0.061^{* * *}$ & $0.061^{* * *}$ & $0.060^{* * *}$ & $0.486^{* * *}$ & $0.081^{* * *}$ \\
\hline & $(15.15)$ & $(15.04)$ & $(14.96)$ & $(144.94)$ & $(18.85)$ \\
\hline \multirow{2}{*}{ Supply Chain Slack ${ }_{t}$} & $0.010^{* * *}$ & & $0.015^{* * *}$ & $0.009^{* * *}$ & $0.015^{* * *}$ \\
\hline & $(2.83)$ & & $(3.93)$ & $(3.14)$ & $(3.88)$ \\
\hline \multirow{2}{*}{$S G \& A$ Slack $_{t}$} & & $-0.028^{* * *}$ & $-0.031^{* * *}$ & $-0.017^{* * *}$ & $-0.034^{* * *}$ \\
\hline & & $(-6.52)$ & $(-7.04)$ & $(-4.95)$ & $(-7.56)$ \\
\hline \multirow{2}{*}{$R O E_{t}$} & $0.021^{* * *}$ & $0.015^{* *}$ & $0.015^{* *}$ & 0.006 & $0.023^{* * *}$ \\
\hline & $(3.31)$ & $(2.26)$ & $(2.37)$ & $(1.20)$ & $(3.56)$ \\
\hline \multirow{2}{*}{$\operatorname{Loss}_{t}$} & $-0.017^{* * *}$ & $-0.016^{* * *}$ & $-0.015^{* * *}$ & $-0.006^{* *}$ & $-0.020^{* * *}$ \\
\hline & $(-4.68)$ & $(-4.51)$ & $(-4.26)$ & $(-2.04)$ & $(-5.40)$ \\
\hline \multirow{2}{*}{ Return $_{t}$} & $0.108^{* * *}$ & $0.105^{* * *}$ & $0.105^{* * *}$ & $0.159^{* * *}$ & $0.113^{* * *}$ \\
\hline & $(24.17)$ & $(23.53)$ & $(23.42)$ & $(42.04)$ & $(24.86)$ \\
\hline \multirow{2}{*}{ Firm Efficiency ${ }_{t}$} & 0.004 & 0.000 & -0.000 & $0.013^{* *}$ & 0.006 \\
\hline & $(0.64)$ & $(0.07)$ & $(-0.04)$ & $(2.38)$ & $(0.86)$ \\
\hline \multirow{2}{*}{ Managerial Ability $_{t}$} & $0.009^{*}$ & 0.008 & 0.008 & $-0.009^{* *}$ & 0.008 \\
\hline & $(1.79)$ & $(1.61)$ & $(1.61)$ & $(-2.11)$ & $(1.46)$ \\
\hline \multirow{2}{*}{$\log (\text { Assets })_{t}$} & $0.152^{* * *}$ & $0.148^{* * *}$ & $0.150^{* * *}$ & $0.111^{* * *}$ & $0.119^{* * *}$ \\
\hline & $(23.12)$ & $(22.47)$ & $(22.71)$ & $(20.22)$ & $(17.65)$ \\
\hline \multirow{2}{*}{ Number of Analysts $t_{t}$} & $0.023^{* * *}$ & $0.023^{* * *}$ & $0.023^{* * *}$ & 0.004 & $0.025^{* * *}$ \\
\hline & $(4.64)$ & $(4.76)$ & $(4.72)$ & $(0.98)$ & $(4.88)$ \\
\hline \multirow{2}{*}{$B / M_{t}$} & $-0.077^{* * *}$ & $-0.083^{* * *}$ & $-0.084^{* * *}$ & $-0.063^{* * *}$ & $-0.085^{* * *}$ \\
\hline & $(-16.20)$ & $(-17.21)$ & $(-17.40)$ & $(-15.99)$ & $(-17.09)$ \\
\hline \multirow{2}{*}{ Return Volatility } & $-0.089^{* * *}$ & $-0.090^{* * *}$ & $-0.089^{* * *}$ & 0.000 & $-0.074^{* * *}$ \\
\hline & $(-14.54)$ & $(-14.60)$ & $(-14.48)$ & $(0.06)$ & $(-11.91)$ \\
\hline \multirow{2}{*}{ Trading Volume } & $0.079^{* * *}$ & $0.079^{* * *}$ & $0.079^{* * *}$ & $0.029^{* * *}$ & $0.069^{* * *}$ \\
\hline & $(16.21)$ & $(16.35)$ & $(16.28)$ & $(7.34)$ & $(14.29)$ \\
\hline \multirow{2}{*}{ Beta $_{t}$} & $-0.105^{* * *}$ & $-0.105^{* * *}$ & $-0.105^{* * *}$ & $-0.036^{* * *}$ & $-0.045^{* * *}$ \\
\hline & $(-27.64)$ & $(-27.81)$ & $(-27.79)$ & $(-11.59)$ & $(-11.69)$ \\
\hline \multirow{2}{*}{$\mathrm{Age}_{t}$} & -0.002 & -0.002 & -0.002 & $0.011^{* * *}$ & 0.002 \\
\hline & $(-0.44)$ & $(-0.34)$ & $(-0.52)$ & $(2.86)$ & $(0.52)$ \\
\hline \multirow{2}{*}{ Accruals $_{t}$} & 0.002 & 0.004 & 0.003 & -0.004 & 0.005 \\
\hline & $(0.68)$ & $(1.06)$ & $(0.95)$ & $(-1.21)$ & $(1.35)$ \\
\hline \multirow{2}{*}{ Cash $_{t}$} & $-0.010^{* *}$ & -0.005 & -0.003 & -0.003 & -0.006 \\
\hline & $(-2.45)$ & $(-1.16)$ & $(-0.70)$ & $(-1.05)$ & $(-1.34)$ \\
\hline \multirow{2}{*}{$L_{R} \operatorname{ETR}_{t}$} & $0.017^{* * *}$ & $0.017^{* * *}$ & $0.016^{* * *}$ & $0.007^{* *}$ & $0.022^{* * *}$ \\
\hline & $(4.28)$ & $(4.23)$ & $(3.86)$ & $(2.11)$ & $(5.28)$ \\
\hline \multirow{2}{*}{ Auditor Tenure ${ }_{t}$} & -0.007 & -0.006 & -0.006 & -0.004 & -0.004 \\
\hline & $(-1.63)$ & $(-1.45)$ & $(-1.41)$ & $(-1.24)$ & $(-1.08)$ \\
\hline Year fixed effects & Yes & Yes & Yes & Yes & Yes \\
\hline Observations & 71,018 & 71,018 & 71,018 & 70,953 & 71,018 \\
\hline Adjusted $\mathrm{R}^{2}$ & $16.7 \%$ & $16.7 \%$ & $16.7 \%$ & $38.0 \%$ & $13.8 \%$ \\
\hline
\end{tabular}

\subsection{The Relation between Operational Slack and Expected Crash Risk}

Table 2 presents the results of Equation (1b), where dependent variable is IVSkewt. The sample is smaller due to the requirement for actively traded options $(\mathrm{N}=25,503$ versus 71,018). Across columns, we find that the coefficients for $S G \& A$ Slack $t$ are consistently negative and significant. That is, investors expect that $S G \& A$ Slack mitigates future crashes. Similar to Panel A, this finding is consistent with investors viewing $S G \& A$ Slack as arising from an insurance motivation. The coefficient for Supply Chain Slack is positive and marginally significant at the 10 percent level. Similar to Panel A, this finding is consistent with investors viewing Supply Chain Slack as arising due to bad news hoarding. When we use raw variables, the signs of coefficient estimates for both slack types are significant. 
Table 2. Slack and Expected Stock Price Crash Risk

\begin{tabular}{|c|c|c|c|c|}
\hline \multirow{3}{*}{ IVSkew $_{t-1}$} & IVSkewt & IVSkewt & IVSkew $_{t}$ & IVSkew $_{t, t+1}$ \\
\hline & $0.345^{* * *}$ & $0.344^{* * *}$ & $0.344^{* * *}$ & $0.288^{* * *}$ \\
\hline & $(46.03)$ & $(45.88)$ & $(45.86)$ & $(36.03)$ \\
\hline \multirow{2}{*}{ Supply Chain Slack } & 0.007 & & $0.010^{*}$ & 0.011 \\
\hline & $(1.25)$ & & $(1.82)$ & $(1.61)$ \\
\hline \multirow{2}{*}{$S G \& A$ Slack $_{t}$} & & $-0.028^{* * *}$ & $-0.029^{* * *}$ & $-0.036^{* * *}$ \\
\hline & & $(-4.57)$ & $(-4.74)$ & $(-4.70)$ \\
\hline \multirow{2}{*}{$R O E_{t}$} & $-0.040^{* * *}$ & $-0.046^{* * *}$ & $-0.045^{* * *}$ & $-0.049^{* * *}$ \\
\hline & $(-4.41)$ & $(-5.05)$ & $(-4.97)$ & $(-4.80)$ \\
\hline \multirow[b]{2}{*}{$\operatorname{Loss}_{t}$} & -0.006 & -0.005 & -0.004 & $-0.012^{* *}$ \\
\hline & $(-1.03)$ & $(-0.87)$ & $(-0.77)$ & $(-1.97)$ \\
\hline \multirow{2}{*}{ Return $_{t}$} & $0.054^{* * *}$ & $0.050^{* * *}$ & $0.050^{* * *}$ & $0.026^{* * *}$ \\
\hline & $(7.68)$ & $(7.22)$ & $(7.20)$ & $(3.81)$ \\
\hline \multirow{2}{*}{ Firm Efficiency $y_{t}$} & 0.016 & 0.011 & 0.011 & 0.006 \\
\hline & $(1.61)$ & $(1.10)$ & $(1.09)$ & $(0.45)$ \\
\hline \multirow{2}{*}{ Managerial Ability $_{t}$} & -0.007 & -0.007 & -0.007 & -0.001 \\
\hline & $(-0.92)$ & $(-0.93)$ & $(-0.97)$ & $(-0.10)$ \\
\hline \multirow{2}{*}{$\log (\text { Assets })_{t}$} & 0.020 & 0.017 & 0.018 & 0.018 \\
\hline & $(1.61)$ & $(1.34)$ & $(1.44)$ & $(1.16)$ \\
\hline \multirow{2}{*}{ Number of Analysts } & -0.010 & -0.009 & -0.010 & $-0.015^{*}$ \\
\hline & $(-1.49)$ & $(-1.46)$ & $(-1.48)$ & $(-1.87)$ \\
\hline \multirow{2}{*}{$B / M_{t}$} & -0.009 & $-0.017^{* *}$ & $-0.017^{* *}$ & $-0.019^{* *}$ \\
\hline & $(-1.17)$ & $(-2.13)$ & $(-2.14)$ & $(-2.00)$ \\
\hline \multirow{2}{*}{ Return Volatility } & $0.178^{* * *}$ & $0.177^{* * *}$ & $0.177^{* * *}$ & $0.192^{* * *}$ \\
\hline & $(17.26)$ & $(17.21)$ & $(17.23)$ & $(16.43)$ \\
\hline \multirow{2}{*}{ Trading Volume $_{t}$} & $-0.021^{* *}$ & $-0.021^{* *}$ & $-0.021^{* *}$ & $-0.025^{* *}$ \\
\hline & $(-2.39)$ & $(-2.39)$ & $(-2.38)$ & $(-2.35)$ \\
\hline \multirow{2}{*}{ Beta $_{t}$} & 0.005 & 0.004 & 0.004 & $0.015^{* *}$ \\
\hline & $(0.70)$ & $(0.60)$ & $(0.61)$ & $(2.22)$ \\
\hline \multirow{2}{*}{$\mathrm{Age}_{t}$} & $-0.018^{* * *}$ & $-0.017^{* * *}$ & $-0.017^{* * *}$ & -0.013 \\
\hline & $(-2.85)$ & $(-2.72)$ & $(-2.80)$ & $(-1.60)$ \\
\hline \multirow{2}{*}{ Accruals $_{t}$} & -0.007 & -0.006 & -0.006 & -0.003 \\
\hline & $(-1.34)$ & $(-1.08)$ & $(-1.13)$ & $(-0.58)$ \\
\hline \multirow{2}{*}{$\operatorname{Cash}_{t}$} & $-0.019^{* * *}$ & $-0.014^{* *}$ & $-0.013^{* *}$ & $-0.019^{* *}$ \\
\hline & $(-3.05)$ & $(-2.18)$ & $(-1.97)$ & $(-2.38)$ \\
\hline \multirow{2}{*}{$L_{R} E T R_{t}$} & 0.008 & 0.007 & 0.006 & 0.010 \\
\hline & $(1.26)$ & $(1.12)$ & $(0.95)$ & $(1.23)$ \\
\hline \multirow{2}{*}{ Auditor Tenure $_{t}$} & $-0.011^{*}$ & $-0.010^{*}$ & $-0.010^{*}$ & $-0.017^{* *}$ \\
\hline & $(-1.95)$ & $(-1.81)$ & $(-1.77)$ & $(-2.48)$ \\
\hline Year fixed effects & Yes & Yes & Yes & Yes \\
\hline Observations & 25,503 & 25,503 & 25,503 & 25,719 \\
\hline Adjusted $\mathrm{R}^{2}$ & $36.4 \%$ & $36.5 \%$ & $36.5 \%$ & $33.7 \%$ \\
\hline
\end{tabular}

In terms of economic significance, moving Supply Chain Slackt from the lower to the higher half of its distribution increases IVSkewt by $(0.010 * 50 \%=) 0.005$ or $1.8 \%$ of standard deviation of IVSkewt, whereas moving SG\&A Slackt from the lower to the higher half of its distribution decreases $I V S k e w t$ by $(0.029 * 50 \%=) 0.015$ or $5.1 \%$ of standard deviation of IVSkewt.

\subsection{The Relation between Costly Slack and Stock Price Crash Risk}

Equation (2) allows for the relation between slack types and crash risk proxies to vary with $R O E_{t}$. We use $R O E$ as our measure of the cost of slack, because $R O E_{t}$ is a common key factor in a firm's equity value (Barth et al. 1998; Hung 2000). The interaction term indicates whether the effect of a slack type is similar across firms with different levels of $R O E_{t}$ and help us differentiate between the validity of the alternative explanations in Section 2.

Copyright by author(s); CC-BY 
Table 3 presents results of Eq. (2) when the dependent variable is NSkew $t_{t+1}$ (Columns 1 and 2 ) and IVSkewt (Columns 3 and 4). The two slack types are interacted with $R O E_{t}$ separately across columns. When the dependent variable is $N_{S k e w_{t+1}}$, we find positive and marginally significant coefficients on $R O E_{t}$ 's interactions with Supply Chain Slack and $S G \& A$ Slack. the dependent variable is IVSkewt, we find positive and statistically significant coefficients on $R O E_{t}$ 's interaction with SG\&A Slack. However, ROEt's interaction with Supply Chain Slack is insignificant. Similar untabulated findings are obtained when we exclude loss firms, use unranked variables, or use Negative Tail Risk $k_{t+1}$ as the dependent variable.

Table 3. Costly Slack and Crash Risk

\begin{tabular}{|c|c|c|c|c|}
\hline \multirow{3}{*}{ Supply Chain Slack ${ }_{t}$} & \multicolumn{2}{|c|}{ Dependent variable $=$ NSkewt +1} & \multicolumn{2}{|c|}{ Dependent variable $=I$ VSkewt } \\
\hline & 0.000 & & 0.011 & \\
\hline & $(0.01)$ & & $(0.85)$ & \\
\hline \multirow{2}{*}{$S G \& A$ Slack $_{t}$} & & $-0.039^{* * *}$ & & $-0.064^{* * *}$ \\
\hline & & $(-5.05)$ & & $(-4.75)$ \\
\hline \multirow{2}{*}{$R O E_{t}$} & 0.012 & 0.005 & $-0.037^{* * *}$ & $-0.076^{* * *}$ \\
\hline & $(1.35)$ & $(0.51)$ & $(-2.95)$ & $(-5.90)$ \\
\hline \multirow{2}{*}{$\begin{array}{l}\text { Supply Chain Slack }{ }_{t}^{*} \\
\text { ROE }_{t}\end{array}$} & $0.021^{*}$ & & -0.008 & \\
\hline & $(1.74)$ & & $(-0.40)$ & \\
\hline \multirow{2}{*}{$S G \& A$ Slack $_{t}^{*} R O E_{t}$} & & $0.022^{*}$ & & $0.066^{* * *}$ \\
\hline & & $(1.69)$ & & $(3.30)$ \\
\hline $\begin{array}{l}\text { Lagged dependent } \\
\text { variable }\end{array}$ & Yes & Yes & Yes & Yes \\
\hline $\begin{array}{l}\text { Financial control } \\
\text { variables }\end{array}$ & Yes & Yes & Yes & Yes \\
\hline Year fixed effects & Yes & Yes & Yes & Yes \\
\hline Observations & 71,018 & 71,018 & 25,503 & 25,503 \\
\hline Adjusted $\mathrm{R}^{2}$ & $16.7 \%$ & $16.7 \%$ & $36.6 \%$ & $36.6 \%$ \\
\hline
\end{tabular}

Table 3 presents results of Eq. (2) when the dependent variable is NSkew $t+1$ (Columns 1 and 2) and IVSkewt (Columns 3 and 4). The two slack types are interacted with $R O E_{t}$ separately across columns. When the dependent variable is

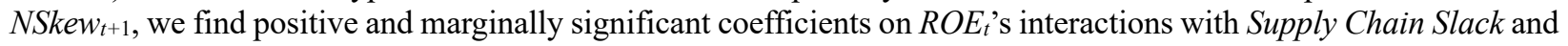
$S G \& A$ Slack. the dependent variable is IVSkewt, we find positive and statistically significant coefficients on ROE's interaction with SG\&A Slack. However, ROEt's interaction with Supply Chain Slack is insignificant. Similar untabulated findings are obtained when we exclude loss firms, use unranked variables, or use Negative Tail Risk $k_{t+1}$ as the dependent variable.

Overall, these findings support our prediction that the implications of operational slack for future crash risk depend on the effect of that slack on current profits. Consistent with the insurance explanation, $S G \& A$ Slack is more likely to decrease realized and expected crash risk when current profits are low (i.e., when there is a cost associated with obtaining the insurance). In addition, consistent with the bad news hoarding explanation, Supply Chain Slack is more likely to increase realized crashes when current profits are high (i.e., when the slack reflects income-increasing earnings management).

\section{CONCLUSION}

Operational slack decisions involve a firm's idling or underusing resources for various reasons (Chopra \& Sodhi, 2004; Tang, 2006). These decisions have become an important part of corporate strategy after the global financial crisis of 2008 (Bodnar et al. 2011; State Street Advisors, 2013). In this paper, we test the validity of a firm's alternative motivations for holding operational slack by examining the relations between different types of operational slack, current profits, and future stock price crash risk. We find that $S G \& A$ Slack is associated with lower current profits and lower future crash risk, consistent with the insurance motivation. Furthermore, Supply Chain Slack is associated with higher current profits and higher future crash risk, consistent with the bad news hoarding motivation. Our evidence does not extend support for the poor management and accommodating growth motivations. Finally, we find that both 
SG\&A Slack and Supply Chain Slack are associated with higher (lower) future crash risk when the firm reports higher (lower) profits. Overall, the findings suggest an overarching trade-off between current profits and future crash risk, which is stronger when companies have operational slack.

Our findings contribute to multiple literatures. First, we reveal conditions where operational slack is more or less likely to reflect earnings management (i.e., a bad news hoarding motivation versus an insurance motivation) and thus benefit the firm by mitigating future crashes. Second, we contribute to the crash risk literature by documenting a novel determinant of crash risk, i.e., operational slack. Finally, we contribute to the risk management literature by highlighting the trade-off between costs and benefits of different types of operational slack. Our results are relevant to both external users of firm financials (investors and policy makers), who use financial ratios to assess corporate risk management policies, and managers evaluating their operational slack policies.

\section{AUTHOR BIOGRAPHIES}

Theodore Goodman is an associate professor of accounting at Purdue University. Email: thgoodma@purdue.edu

Volkan Muslu is an associate professor of accounting at University of Houston. Email: vmuslu@uh.edu

Hyungshin Park is an associate professor of accounting at Santa Clara University. Email: hpark2@scu.edu

\section{REFERENCES}

Anderson, M. C., Banker, R. D., \& Janakiraman, S. N. (2003). Are selling, general, and administrative costs "sticky"?, Journal of Accounting Research, 41 (1), 47-63.

Anderson, M., Banker, R., Huang, R., \& Janakiraman, S. (2007). Cost behavior and fundamental analysis of SG\&A costs. Journal of Accounting, Auditing, and Finance, 22 (1), 1-28.

Ang, A., Chen, J., \& Xing, Y. (2006). Downside risk. Review of Financial Studies, 19 (4), 1191-1239.

Baird, I. S., \& Thomas, H. (1990). What is risk anyway? Using and measuring risk in strategic management. In R.A. Bettis \& H. Thomas (Eds.), Risk, Strategy, and Management (pp. 21-52). Greenwich, CT: JAI Press.

Bernard, V., \& Noel, J. (1991). Do inventory disclosures predict sales and earnings? Journal of Accounting, Auditing, and Finance 6, 145-179.

Bodnar, G. M., Graham, J., Harvey, C. R., \& Marston, R. C. (2011). Managing risk management. Working paper, John Hopkins University.

Bollen, N., \& Whaley, R. (2004). Does net buying pressure affect the shape of implied volatility functions? Journal of Finance, 59 (2), 711-753.

Bollerslev, T., \& Todorov, V. (2011). Tails, fears, and risk premia. Journal of Finance, 66 (6), 2165-2211.

Bushee, B. J. (1998). The influence of institutional investors on myopic R\&D investment behavior. The Accounting Review, 73 (3), 305-333.

Callen, J. L., \& Fang, X. (2017). Crash risk and the auditor-client relationship. Contemporary Accounting Research, 34 (3), $1715-1750$

Chen, J., Hong, H., \& Stein, J. (2001). Forecasting crashes: Trading volume, past returns, and conditional skewness in stock prices. Journal of Financial Economics, 61, 345-381.

Chopra, S., \& Sodhi, M. S. (2004). Managing risk to avoid supply-chain breakdown. MIT Sloan Management Review, 46 (1), 5361.

Cohen, D., Mashruwala, R., \& Zach, T. (2010). The use of advertising activities to meet earnings benchmarks: Evidence from monthly data. Review of Accounting Studies, 15 (4), 808-832.

Collins, J. M., \& Ruefli, T. W. (1992). Strategic risk: An ordinal approach. Management Science, 38, 1707-1731.

Cunat, V. (2007). Trade Credit: Suppliers as debt collectors and insurance providers. The Review of Financial Studies, 20 (2), 491-527.

Daniel, F., Lohrke, F. T., Fornaciari, C. J., \& Turner, R. A. (2004). Slack resources and firm performance: A meta analysis. Journal of Business Research, 57 (6), 565-574.

Demerjian, P., Lev, B., \& McVay, S. (2012). Quantifying managerial ability: A new measure and validity tests. Management Science, 58 (7), 1229-1248.

Driouchi, T., \& Bennett, D. (2011). Real options in multinational decision-making: Managerial awareness and risk implications. Journal of World Business, 46 (2), 205-219.

Dumas, B., Fleming, J., \& Whaley, R. E. (1998). Implied volatility functions: Empirical tests. Journal of Finance, 53 (6), $2059-$ 2106.

Copyright by author(s); $\underline{\text { CC-BY }}$ 
Dyreng, S.D., Hanlon, M., \& Maydew, E. L. (2008). Long-run corporate tax avoidance. The Accounting Review, 83, 61-82.

Eroglu, C., \& Hofer, C. (2011). Lean, leaner, too lean? The inventory-performance link revisited. Journal of Operations Management, 29, 356-369.

Fairfield, P. M., Whisenant, J. S., \& Yohn, T. L. (2003). The differential persistence of accruals and cash flows for future operating income versus future profitability. Review of Accounting Studies, 8, 221-243.

Francis, B., I. Hasan, \& Lingxian, L. (2016). Abnormal real operations, real earnings management, and subsequent crashes in stock prices. Review of Quantitative Finance and Accounting, 46 (2):217-260.

George, G. (2005). Slack resources and the performance of privately held firms. The Academy of Management Journal, 48 (4), $661-676$.

Greenley, G. E., \& Oktengil, M. (1998). A comparison of slack resources in high and low performing British companies. Journal of Manaegment Studies, 35 (3), 377-398.

Harlow, W. V., \& Rao, R. K. S. (1989). Asset pricing in a generalized mean-lower partial moment framework. Journal of Financial and Quantitative Analysis, 24, 285-311.

Hendricks, K. B., Singhal, V. R., \& Zhang, R. (2009). The effect of operational slack, diversification, and vertical relatedness on the stock market reaction to supply chain disruptions. Journal of Operations Management, 27, 233-246.

Hirshleifer, D., Hou, K., \& Teoh, S. (2004). Do investors overvalue firms with bloated balance sheets?, Journal of Accounting and Economics, 38, 297-331.

Hutton, A. P., Marcus, A. J., \& Tehranian, H. (2009). Opaque financial reports, R², and crash risk. Journal of Financial Economics, 94 (1), 67-86.

Jin, L., \& Myers, S. C. (2006). R² around the world: New theory and new tests. Journal of Financial Economics, 79 (2), $257-$ 292.

John, K., Li, Y., \& Pang, J. (2017). Does corporate governance matter more for high financial slack firms? Management Science, 63 (6), 1872-1891.

Kahneman, D., Slovic, P., \& Tversky, A. (1982). Judgement under Uncertainty: Heuristics and Biases. Cambridge University Press

Kim, J. B., Li, Y., \& Zhang, L. (2011a). Corporate tax avoidance and stock price crash risk: Firm-level analysis. Journal of Financial Economics, 100 (3), 639-662.

Kim, J. B., Li, Y., \& Zhang, L. (2011b). CFOs versus CEOs: Equity incentives and crashes. Journal of Financial Economics, 101 (3), 713-730.

Kim, J., Li, L., Lu, L., \& Yu, Y. (2016). Financial statement comparability and expected crash risk. Journal of Accounting and Economics, 61, 294-312.

Kovach, J. J., Hora, M., Manikas, A., \& Patel, P. C. (2015). Firm performance in dynamic environments: The role of operational slack and operational scope. Journal of Operations Management, 37, 1-12.

Miller, K. D., \& Reuer, J. J. (1996). Measuring organizational downside risk. Strategic Management Journal, 17 (9), $671-691$.

Mishina, Y., Pollock, T. G., \& Porac, J. F. (2004). Are more resources always better for growth? Resource stickiness in market and product expansion. Strategic Management Journal, 25 (12), 1179-1197.

Modi, S. B., \& Mishra, S. (2011). What drives financial performance-resource efficiency or resource slack?: Evidence from US Based Manufacturing Firms from 1991 to 2006. Journal of Operations Management, 29 (3), 254-273.

Porter, M. E. (1985). Competitive Advantage: Creating and Sustaining Superior Performance. Free Press, New York.

Reuer, J. J., \& Leiblein, M. J. (2000). Downside risk implications of multinationality and international joint ventures. Academy of Management Journal, 43 (2), 203-214.

State Street Advisors. (2013, May 7). Closing the communications gap: How institutional investors are building risk aware cultures. Economistinsights.com.

Sun, Y. (2010). Do MD\&A disclosures help users interpret disproportionate inventory increases?. The Accounting Review, 85(4), 1411-1440.

Tang, C. S. (2006). Robust strategies for mitigating supply chain disruptions. International Journal of Logistics: Research and Applications, 9 (1), 33-45.

Wefald, A. J., Katz, J. P., Downey, R. G., \& Rust, K. G. (2010). Organizational slack, firm performance, and the role of industry. Journal of Management Issues, 22 (1), 70-87.

Wilner, B. (2000). The exploitation of relationships in financial distress: The case of trade credit. Journal of Finance, 55 (1), 153-178.

Zhu, W. (2016). Accruals and price crashes. Review of Accounting Studies, 21 (2), 349-399. 


\section{APPENDIX}

\section{Variable Definitions}

\begin{tabular}{|c|c|}
\hline Accruals & $\begin{array}{l}\text { Change in net operating assets, computed as total assets }(a t) \text { - cash and short-term investments }(\text { che }) \text { - } \\
\text { total liabilities }(l t)+\text { debt in current liabilities }(d l c)+\text { long-term debt }(d l t t) \text {, deflated by total assets. The } \\
\text { data is obtained from the CRSP/Compustat database. }\end{array}$ \\
\hline Age & $\begin{array}{l}\text { The number of years since the firm's stock appeared in the CRSP/Compustat database (1980 is the } \\
\text { starting year). }\end{array}$ \\
\hline Auditor Tenure & $\begin{array}{l}\text { The number of years the incumbent auditor has been auditing the firm (Source: Audit Analytics) (Callen } \\
\text { \& Fang, 2017). }\end{array}$ \\
\hline$B / M$ & Book value of total assets divided by market value of total assets. \\
\hline Beta & $\begin{array}{l}\text { The firm's industry slope coefficient, defined as } \beta_{1} \text { in the following firm-year-specific regression } \\
\text { below: } \\
\operatorname{Ret}_{f, w}=\alpha+\beta_{1} \operatorname{Ret}_{i, w}+\beta_{2} \operatorname{NegRet}_{i, j}+\beta_{3} \operatorname{Ret}_{i, w} * \operatorname{NegRet}_{i, w}+\varepsilon_{f, w} \\
\text { where } \operatorname{Ret}_{f, w} \text { is weekly return of firm } f, \operatorname{Ret}_{i, w} \text { is average weekly return of SIC 2-digit industry } i \text { that } \\
\text { firm } f \text { belongs to, and } \operatorname{NegRet}_{i, w} \text { is an indicator that is one if } \operatorname{Ret}_{i, w} \text { is negative. }\end{array}$ \\
\hline Cash & Cash and short-term investments divided by total assets. \\
\hline DNSkew & Skewness coefficient of the firm's daily stock returns multiplied by $(-1)$ \\
\hline Firm Efficiency & $\begin{array}{l}\text { Demerjian et al.'s (2012) measure of total firm efficiency, measuring the firm's ability in transforming } \\
\text { corporate resources to revenue. The data is obtained from Sarah McVay's research website } \\
\text { (Source: http://faculty.washington.edu/smcvay/abilitydata.html). }\end{array}$ \\
\hline Hedge Activity & Indicator that is one if the firm reported non-zero hedging gains and losses. \\
\hline IV_Skew & $\begin{array}{l}\text { Weighted average of daily differences between implied stock return volatilities of out-of-the-money } \\
\text { put options and at-the-money call options over the } 12 \text { months ending three months after the end of } \\
\text { fiscal year. }\end{array}$ \\
\hline $\log ($ Assets $)$ & Natural logarithm of total assets. \\
\hline Loss & Indicator that is one if income before extraordinary items is negative. \\
\hline LRETR & $\begin{array}{l}\text { Long-run effective tax rate is computed as the sum of income tax paid (txpd) over the previous five } \\
\text { years divided by the sum of a firm's pre-tax income minus special items ( } p i-s p i) \text { (Dyreng et al. 2008). } \\
\text { Missing special items are set to zero. LR ETR is winsorized at } 0 \text { and } 1 \text {. }\end{array}$ \\
\hline Managerial Ability & $\begin{array}{l}\text { Demerjian et al.'s (2012) measure of managerial ability, which is the residual firm efficiency that cannot } \\
\text { be explained by firm-specific variables. }\end{array}$ \\
\hline Negative Special Items & Indicator that is one if special items is negative. \\
\hline Number of Analysts & The number of analysts making stock recommendations on the firm. \\
\hline NSkew & Skewness coefficient of the firm's weekly stock returns multiplied by $(-1)$. \\
\hline Return & Annual raw stock returns. \\
\hline Return Volatility & Standard deviation of weekly stock returns. \\
\hline ROE & Net income divided by shareholder's equity. \\
\hline SG\&A Slack & SG\&A expense divided by sales revenue. \\
\hline Supply Chain Slack & $\begin{array}{l}\text { Length of the operating cash cycle, measured as total inventory divided by cost of goods sold (Inventory } \\
\text { Slack), plus total receivables divided by sales revenue (Receivables Slack), minus accounts payable } \\
\text { divided by cost of goods sold (Payables Slack). }\end{array}$ \\
\hline Trading Volume & Annual trading volume divided by the average number of shares outstanding. \\
\hline
\end{tabular}


NOTES 